\title{
Ankara'nın Sof Üretiminin Osmanlı Devleti Ticaretindeki Yeri ve Önemi
}

\author{
The Place and Importance of Ankara's Sof Production in the Trade of the Ottoman \\ Empire
}

Perihan Hazel KAYA *

$\ddot{O} Z$

Osmanlı döneminde Ankara, Anadolu’nun önemli bir ticaret merkezi olarak karşımıza çıkmaktadır. Tiftik keçisi yetiştiriciliğinde uzmanlaşan Ankara'da bu keçilerden elde edilen tiftikten dokunan bir kumaş olan sofun şehrin ekonomik ve sosyal hayatında önemli bir yeri bulunmaktadır. Coğrafi olarak Anadolu'nun merkezinde ve ticaret yollarının geçiş güzergahları üzerinde bulunan Ankara'da sof üretiminin önemi yerli ve yabancı tüccarları bu şehirde ticari faaliyetlerde bulunmaya yönlendirmiştir. Bu çalışmada, Osmanlı Devleti döneminde Ankara'nın sof üretimi ve ticareti incelenerek genel özellikleri değerlendirilmiştir. Ayrıca bu yolla Ankara'nın sof üretimine dayalı ticaretinin Osmanlı Devleti'nin ticari hayatındaki yeri ve önemi Şer'iye sicillerindeki belgeler yardımıyla gözler önüne serilmeye çalışılmış ve XIX. yüzyılın sonlarında sof üretiminin ve bu üretime dayalı ticaretin azalmasının nedenleri araştırllmıştır. Araştırmalar sonucunda Ankara'nın sof üretimi ve ticaretinde XVI.-XVIII. yüzyllar boyunca hem Osmanlı Devleti'nde hem de Avrupa'da lider konumda olduğu ancak XIX. yüzyllın başlarından itibaren bu konumunu kaybettiği görülmüştür. Bu kaybın en önemli nedeni ise Sanayi Devrimi sonrası dönemde Ingilizlerin dokuma sektöründe lider konuma gelmesi ve Afrika'da tiftik keçisi yetiştirmeye başlamasıdır.

ANAHTAR KELIMELER

Sof üretimi, Sofa Dayalı Ticaret, Ankara, Osmanlı Devleti, Ingilizler

\begin{abstract}
During the Ottoman period, Ankara emerges as an important trade center of Anatolia. In Ankara, which specializes in raising angora goats, as a fabric woven from angora made from these goats, the sof has an important place in the economic and social life of the city. The importance of sof production in Ankara, which is geographically located in the center of Anatolia and on the transit routes of trade routes, has led local and foreign merchants to engage in commercial activities in this city. In this study, the general characteristics of Ankara's sof production and trade were examined during the Ottoman period. In addition, in this way, the place and importance of Ankara's trade based on sof production in the commercial life of the Ottoman Empire was tried to be revealed with the help of archival documents and the reasons for the decrease in sod production and trade based on this production were investigated at the end of the XIX. century. As a result of the researches, it is stated that Ankara has a leading position both in the Ottoman Empire and in Europe in the production and trade of sof in the XVI.-XVIII. centuries however, it was observed that it lost this position since the beginning of the XIX. century. The most important reason for this loss is that after the Industrial Revolution, the British became a leader in the weaving industry and started raising angora goats in Africa.
\end{abstract}

\section{KEYWORDS}

Sof production, Sof Based Trade, Ankara, Ottoman Empire, British

\begin{tabular}{|c|c|c|}
\hline \multicolumn{2}{|r|}{$\begin{array}{c}\text { Makale Geliş Tarihi / Submission Date } \\
01.02 .2021\end{array}$} & $\begin{array}{c}\text { Makale Kabul Tarihi / Date of Acceptance } \\
\text { 07.04.2021 }\end{array}$ \\
\hline Atıf & $\begin{array}{l}\text { Kaya, P. H. (2021). Ankara'nın Sof Ü } \\
\text { Sosyal Bilimler Meslek Yüksekokulu D }\end{array}$ & leti Ticaretindeki Yeri ve Önemi. Selçuk Üniversitesi \\
\hline
\end{tabular}

\footnotetext{
* Dr. Öğr. Üyesi, Selçuk Üniversitesi İktisadi ve İdari Bilimler Fakültesi, perihaner@selcuk.edu.tr, ORCID: 0000-0002-9878-4194
} 


\section{GÍRİ̧̧}

Osmanlı Devleti'nin taşra idaresi yukarıdan aşağıya eyalet, sancak, kaza, nahiye ve karye şeklinde teşkilatlanmıştır. Kendine bağlı köylerin birleşmesiyle nahiyeler, nahiyelerin birleşmesi ile kazalar, kazaların birleşmesiyle sancaklar, sancakların birleşmesiyle de eyaletler oluşmuştur. Osmanlı döneminde Ankara kenti de bu teşkilatlanmanın önemli bir parçası olarak yer almaktadır. 1462 yılına kadar Anadolu eyaletinin paşa sancağı konumunda olan Ankara bu tarihten sonra Kütahya'nın eyalet merkezi olması ile önemli bir sancak durumuna gelmiştir.

Şehirlerin gelişmesinde ve kalkınmasında sahip oldukları doğal kaynaklar ve bu kaynakların kullanımı önem arz etmektedir. Ankara tiftik keçisi yetiştiriciliğinde uzmanlaşmış bir Osmanlı kentidir. Tarihsel süreçte Ankara'nın ekonomik ve sosyal yaşamında Ankara keçisinin tiftiğinden üretilen sof kumaşların önemli bir yeri vardır. Sofa dayalı üretimin Ankara ve yöresinde ne zaman başladığı kesin olarak bilinmemekle beraber sof kumaşı tiftik keçisinden yapıldığı için başlangıcının tiftik keçisinin Anadolu'ya gelişi ile yakından ilgili olduğu düşünülmektedir.

XIV. yüzyıldan itibaren Ankara bir ticaret kenti olarak karşımıza çıkmaktadır. Kentte tarımsal faaliyetlerin yanı sıra sanayi ve ticarette görülen artış ile sof ticareti önem kazanmıştır. Tiftik keçisinin tüylerinden üretilen sof ve şal gibi kumaşlar, Ankara'daki yerli ve yabancı tüccarlara önemli kazançlar sağlamaktaydı. Başlarda toplumun elit kesimleri tarafından tercih edilen sof kumaşı daha sonralarda tüm dünyaya yayılarak, önemli bir ihraç kalemi haline gelmiş ve özellikle XVI.-XVIII. yüzyıllar boyunca kentin ekonomik ve sosyal yaşamına büyük bir canlılık katmıştır. Bu yolla Ankara kenti, kent ve yakın çevresinde dokunan soflarıyla hem Osmanlı Devleti'nde hem Avrupa'da ün yapmışt1.

Bu çalışmanın amacı, Osmanlı döneminde Ankara'daki sof üretiminin Osmanlı Devleti ticaretindeki yeri ve önemini arşiv belgeleri doğrultusunda ortaya koymaktır. Bu doğrultuda ilk olarak Osmanlı döneminde Ankara şehrinin genel görünümü ve ekonomik yapısından bahsedilmiştir. İkinci olarak şehrin ekonomik faaliyetleri içerisinde en büyük paya sahip olan sof üretiminin arka planı ve gelişimi üzerinde durulmuştur. Son olarak ise Ankara'da sof üretimine dayalı ticaretin yüzyıllar içerisindeki gelişimine dikkat çekilerek XIX. yüzyılın sonlarında sof üretimi ve ticaretinin neden bitme noktasına gelindiği sorularına cevaplar aranarak çalışma tamamlanmıştır.

\section{ANKARA ŞEHRINIIN GENEL GÖRÜNÜMÜ VE EKONOMISİ}

Osmanlı Devleti XVI. yüzyılda altı eyalete ayrılmış ve Ankara da Anadolu Eyaletine bağlı bir sancak olarak merkezi bir konumda yer almıştır (Çadırcı, 1991: s. 89).

İç Anadolu'nun kuzey-batısında, Orta Anadolu'da, fakat İç Karadeniz bölgesinin dağlık yörelerinden uzak ve korunmaya elverişli konumu nedeniyle Ankara'nın, ilk çağlardan itibaren kervan yollarının uğrağı olduğu bilinir. Bursa'yı Tebriz'e bağlayan İpek yolu, Antalya üzerinden İskenderiye deniz yoluna bağlanan yol, Halep'e uzanan ve Anadolu'yu çaprazlama geçen bir başka ticaret yolu Ankara'nın transit ticarette önemini belirlerler (Ergenç, 1980: s. 87).

Arşiv kayıtları doğrultusunda Ankara'da önemli bir nüfusun yaşadığı söylenebilir. Ayrıca tarımsal üretim ve tüketim miktarları Ankara'daki nüfus yoğunluğunun önemli bir göstergesidir. XVII. yüzyılın başlarında 25.000 civarında olduğu tahmin edilen nüfus XVIII. yüzyılda 20.000 civarına düşmüştür (Ergenç, 2012: s. 6061). Yaşanan bu düşüşün nedenleri arasında kıtlık, eşkıyalık olayları ve devletin özellikle savaş dönemlerinde halka yüklediği yükümlülükler yer almaktadır (Akyüz, 2003: s. 84). Bu nedenler arasında en önemlisi ise Celali İsyanlarının yarattığı tahribattır. Celali isyanları sonucu şehirden önemli ölçüde göç olmuş, tarımsal üretim azalmış ve tüm bunlar sonucu kıtlık yaşanmıştır (Akdağ, 1995: ss. 418-421).

Toplumsal ilişkiler bakımından önemli konulardan biri de insanlar tarafından çeşitli malların üretilmesi ve bu üretilen malların tüketiciye dağıtılması hizmetlerinin görülmesi olan ekonomik faaliyetlerdir. Bir toplumda ekonomik faaliyetler tarım, sanayi ve ticaret olmak üzere üçe ayrılır. Osmanlı Devleti’nde birçok şehir gibi Ankara'da nüfusun büyük bölümü geçimini tarımdan ve XVIII. yüzyıla kadar da tiftik ve softan kazanmıştır. Ankara merkezde Keçiviran, Ayvalık, İncirlik, Solfasol, Çinçin Bağları, Cebeci Bağları, Büyük ve Küçük Esad gibi yerlerde bağ ve bahçe tarımı haricinde yakın çevresinde bugünkü Çubuk suyunun geçtiği güzergâhlarda bahçe-bostan tarımı varken Miranos ve Erkeksu gibi köylerde ise sadece sofculuk yapılmaktaydı (Özdemir, 1986: s. 217).

Osmanlı Devletinde kentsel bölgelerin kendi tüketimleri için tarımsal olmayan üretim örgütleri söz konusudur. Bazı kentler, hizmeti bölge dışına taşan yoğun üretimi ile imparatorluk ekonomisine önemli katkılarda bulunabilecek tarzda bir sanat kolunda uzmanlaşmışlardı (Ergenç, 2012: ss.116-117). Osmanlı döneminde Ankara'da tekstilden, ev mutfak araç-gereçlerine, temizlik malzemelerinden, yiyecek, silah 
üretimine, sağlık hizmetlerinden taşımacılık hizmetlerine kadar birçok alanda faaliyet gösteren esnaf kesimi bulunmaktadır (Akyüz, 2003: s. 125).

Günümüzde esnaf denildiğinde şehir ve kasabalarda mal ve hizmet üretimi ile uğraşan kişiler akla gelirken Osmanlı döneminde ise sınırlı zümreler halinde her mal ve hizmet için ayrı birer birim oluşturan kuruluşlar anlaşılmaktaydı (Genç, 1986: s.113).

Tablo I. XVI.-XVIII. Yüzyıl boyunca Ankara'da faaliyet gösteren temel esnaf grupları

\begin{tabular}{|c|c|c|c|c|c|}
\hline Arıc1 & Aktar & Bezci & Berber & Bakkal & Bezirci \\
\hline Bostanc1 & Boyacı & Basmacı & Börekçi & Barutçu & Çilingir \\
\hline Çadırc1 & Helvac1 & Dülger & Debbağ & Dellak & Demirci \\
\hline Duhanc1 & Eskici & Ekmekçi & Haffaf & Kasap & Keçeci \\
\hline Katırc1 & Ketenci & Kömürcü & Tüfekçi & İğneci & İplikçi \\
\hline Kurşuncu & Kahveci & Kantarcı & Kürekçi & Kürkçü & Mumcu \\
\hline Mesçi & Nalband & Nalçacı & Şerbetçi & Pabuçcu & Pekmezci \\
\hline Tüfekçi & Kuyumcu & Pirinçci & Sabuncu & Neccar & Saraç \\
\hline Semerci & Sofçu & Yorganc1 & Taşç & Tekneci & Tellal \\
\hline Palac1 & Pideci & Yemişçi & Testici & Yağc1 & Kütükçü \\
\hline Habbaz & Dikici & Abacı & Muytab & Urganc1 & Cullah \\
\hline Ketenci & Tiftikçi & Çırrıçı & Kalayc1 & K1lıçc1 & Hançerci \\
\hline
\end{tabular}

Kaynak: Akyüz, 2003: 124-125

XVI.-XVIII. yüzyıllar boyunca Ankara'da tarımsal üretim önemli olmakla birlikte tarım dışında çeşitli eşya, alet ve hizmetin üretildiği bir esnaf teşkilatının varlığı da görülmekteydi. Osmanlı döneminde Ankara'da faaliyet gösteren temel esnaf gruplarını kısaca sıralayacak olursak;

- Gıda maddeleri satanlar: Yağc1, kasap, kahveci, habbaz, bezirci, duhanc1, bakkal, helvacı, börekçi, pekmezci.

- Dokumacılık alanında: dikici, Abacı, iğneci, iplikçi, muytab, boyacı, urganc1, keçeci, basmacı, kürkçü, cullah, ketenci, sofçu, çadırc1, tiftikçi.

- Dericilik alanında: Çıkrıkçı, haffaf, pabuçcu, debbağ.

- Alet imalatı alanında: Barutçu, dülger, tekneci, taşçı, hançerci, kalaycı, kılıçcı, semerci, çilingir, demirci, neccar, kurşuncu, tüfekçi, nalband, nalçacı.

- Diğer meslek gruplart: Berber, arıc1, aktar, koyuncu, dellak, saraç, katırc1, tellal, eskici.

17. yüzyılda sof imalatının Ankara' da var olduğu, bununla birlikte belgelerde kuşakçılar ve tiftik boyacıları adıyla yine hammaddeye bağımlı iki ayrı esnaf grubunun 17. yüzyılda varlık gösterdikleri bildirilmektedir (Taş, 2006). Ankara'da sof üretimi ve sofa üretimine dayalı ticaret şehrin gelişimini, ticari faaliyetlerini ve nüfus yoğunluğunu arttıran en önemli etkenlerden birisi olarak da dikkat çekmekteydi. Ankara'nın çok eski zamanlardan beri ticaret yollarının güzergahında bulunması şehirde yoğun bir sof üretiminin ve sofa dayalı bir sanayi ticaretinin bulunmasından kaynaklanmaktaydı (Tunçer, 2001: s.33).

XVI.- XVIII. yüzyıllar boyunca tiftik ve sofun Ankara'nın en önemli gelir kaynağı olması, beraberinde güçlü bir esnaf örgütlenmesini getirmiş ve sof esnafı da kendi içerisinde yuyucular, dokuyucular, boyacılar ve cendereciler şeklinde örgütlenmişlerdir (Ergenç, 1980).

\section{ANKARA'DA SOF ÜRETIMI}

Ankara'da geleneksel üretim organizasyonu içerisinde her çeşit tarım dışı eşya, alet ve hizmet üretildiği, pazar için üretim yapan gelişmiş bir esnaf örgütlemesine de sahip olduğu da görülmektedir. Şehrin merkezini belirleyen ve fiziki oluşumunda büyük katkısı olan en önemli ekonomik ve ticari meta ise, daha önce de belirttiğimiz gibi sof idi (Tunçer, 2001: s.33).

Yün, yapağı ve peşm gibi anlamları olan sof ince keçi kılından dokunan bir kumaşın adı olup en meşhur olanı Ankara sofudur (Pakalın, 1993:s. 241). Sofçuluğun Ankara ve çevresinde ne zaman başladığı kesin olarak bilinmemekle birlikte tiftik keçisinin Anadolu'ya gelişi ile bu üretim dalının ortaya çıktığı söylemek pek yanlış 
olmaz. Evliya Çelebi tiftik keçisinden şu şekilde bahsetmektedir: "Süt gibi beyaz olup onun gibi beyaz mahlûk yoktur. Sof ipliği bunların yününden meydana gelir" (Çelebi, 2008). Tiftik keçisinin kıllarından elde edilen ipliğin dokunmasıyla elde edilen sof kumaşı Osmanlı döneminde giyim kuşam endüstrisinde çok önemli bir yere sahipti. Yüzy1llar boyunca dünya üzerinde sadece Anadolu'da ve özellikle Ankara'da yetiştirilen Ankara keçisinden elde edilen tiftik ipliği XV. yüzyıldan sonra dokuma sektöründe önemli bir noktaya gelmiştir (Ankara Kalkınma Ajansı, 2018: s.10).

Sof kumaşı, tiftik keçisinin yününün liflerinin düzgün ve uzunluğundan dolayı parlak ve dökümlü bir özelliğe sahip olduğundan öncelikle toplumun üst tabakalarının kullandığı bir meta idi. Ayrıca tiftik keçisinin yününün lifleri, hafif yağlı olduğu için yağmurluk yapımında tercih edilirdi. Bir de gömleklik ve şali adı verilen ikinci sınıf ve daha ince soflar da iç giyim eşyasında kullanılmaktaydı. Sof kumaşı sağlamlığından dolayı giyim eşyası yapımında kullanılmasının yanı sıra Tersane-i Amire tarafından da çok miktarda satın alınıyordu (Taş, 2006: s. 88).

Sofun hammaddesi tiftik olmakla beraber beyazlığı göz kamaştırıcı bir nitelikteydi. Tiftikler Mayıs ayına doğru yıkanmadan kırkılır, eğrilir ve iplik haline getirilerek tezgâhlarda dokunurdu. Tezgâhtan çıkan sofların yıkanması, cenderelenmesi (sıkıştırılması), boyanması ve perdahtlanması (cilalanması) gerekmekteydi. Bu zorlu işlemlerin aynı anda yapılması gerekmekteydi. Bu nedenle pek çok işçi aynı anda koordineli olarak çalışırd1. Bu işlerle uğraşan esnaflardan, sofu tezgâhlarda işleyen ve dokuyan ustalar genellikle Müslüman iken yıkayan, cendereleyen, boyayan ve perdahtlayanlar ise genellikle gayrimüslim idi (Tunçer, 2001: s.35).

Ankara'da sof üretimi damga mukâtaası içerisinde gerçekleştirilmekteydi. Damga mukâtaasında, sof dokumasında kullanılan ipliklerin üreticileri tarafından öncelikle sokak ve mahalle satılması daha sonrasında eğer artan kısım olursa iplikçi esnafına satılması; iplik satın alımında dokuyucuların önceliği olması ve hiçbir aracı olmadan ucuz mal almaları sağlanılarak üretimin teşvik edilmesi amaç edinilmiştir. Sofların yıkanma, boyanma, perdahtlanma ve satış işlemleri belli yerlere mahsustur. Dokuma işlemlerini kimin gerçekleştireceği eminin iznine bağlıdır. Dokuma dışındaki işlemlerin belli bölgelere tahsis edilmesi damga eminlerinin yıkama, boyama ve perdahtlama işlemlerinden vergi almasını kolaylaştırmaktadır. Satışlar yalnızca bedestendeki sofcu esnafına yapılabilirdi ki bu yolla damga vergisinin kaçırılması engellenmeye çalışılmaktaydı (Karaman, 2005: s.191).

Ankara'da sof üretimin evlerde dokunduğu veya iplik haline getirildiği bilinmektedir. Sofçular, yoğun olarak şehrin doğusunda Avancıklar Mahallesi'nde otururlardı. Ayrıca şehrin batısında İstanos (Zir), Erkeksu, Miranos gibi köylerde de sof dokuma tezgâhları vardı (Erdoğan A. vd, 2007: s. 98). XVIII. yüzyılın ortalarında Ankara'da sof ve şali üretimi 20.000 top civarındadır. Bu üretim her biri 6 tezgâhı bulunan 8 ila 10 imalathanede gerçekleştirilmekteydi (Sahillioğlu, 1968: s.66). 1114/1702 tarihinde Hacı Doğan mahallesinde üç tezgahlı sof kârhanesi 380 kuruşa gayri müslim Mikail'e satılmıştır (AŞS, 80: s.699). Sof ve şali üretimi kazançlı bir iş olduğundan verimsiz dükkanlar sof üretimi için kârhanelere dönüştürülmüştür. Örneğin 1213/1798 tarihinde Ankara'nın Tulice Mahallesinde Muarrifzade vakfına ait dükkanlar zarar ettikleri için sof kârhaneleri haline getirilmiştir (AŞS, 191/12).

Sofçulukla ilgili esnaf dallarından biri cendereciliktir. Arşiv kayıtlarında sof üretiminde kullanılmak üzere cendere olarak kullanılan bu mülklerin satışına dair belgeler yer almaktadır. Sof üreticiliği önemli bir faaliyet olduğu için kimi zaman bu mülklerin satış fiyatı ev fiyatlarından daha yüksek olabilmekteydi. Örneğin, belgelerden birinde cenderehanenin 500 kuruşa sof üretimi yapmak isteyen birine satıldığ belirtilmektedir (AŞS,133: s.212). Ankara'nın Behlül mahallesinde içinde üç adet dokuma tezgâhı bulunan bir ev 60.000 akçeye satılmıştır (AŞS, 21: s. 67/7 ). Diğer bir örnekte ise Ankara'nın Hendek Mahallesi'nde içerisinde beş adet tezgâhı bulunan kârhane 300 kuruşa satılmıştır (AŞS, 24: s.33/381). Sicillerde yer alan ev satışlarına dair kayıtlarda evlerin içinde bir ila beş arasında sof dokuma tezgâhları olduğundan ayrıca sof kârhanesi olarak kullanılan evlerin çoğunun bir bölümünün de boyahane olarak kullanıldığından bahsedilmektedir (AŞS, 21; $24 ; 133 ; 84 ; 131)$.

\section{ANKARA'DA SOF ÜRETIMINE DAYALI TICARET}

XV. ve XVIII. yüzyıllar boyunca Ankara, özellikle sof üretiminde uzmanlaşmış ve gelişiminin çoğunu bu ürünün Doğu ve Batı pazarlarındaki satışından elde eden bir ticaret kentidir.

XVI. yüzyılda Ankara'daki esnaf teşkilatının içinde sofcuların dışındakilerin nerdeyse hepsinin üretimleri şehir ve civarın ihtiyaçlarını karşılama doğrultusunda şekillenmişti. Ama Ankara'nın tiftik keçisinden üretilen soflar sadece iç piyasa için değil dış piyasaların artan taleplerini karşılamak için de üretilmekteydi. Sof kumaşları bu dönemde büyük bir ticaretin konusu ve Ankara için büyük bir gelir kapısıydı (Ergenç, 2012: s.153). Bu yüzyılda Ankara'ya gelen birçok seyyah tiftik ipliklerinin güzelliği ve parlaklığından, yerli halkın 
dokuduğu sof kumaşlarının kalitesinden ve en böylesi sof kumaşların Avrupa'da olmadığından bahsetmiştir (Faroqhi, s. 263).

Anadolu'yu XV.-XVII. yüzyıllar arasında dolaşan seyyahlar, tiftik keçilerinin Sakarya ve Kızılırmak nehirleri arasındaki bölgede yetiştirildiğini bildirmişlerdir. Bu keçilerin tüylerinin ipek gibi ince ve parlak, yapağılarından üretilen kumaşın ise çok zarif olduğunu belirtmiştir. Ayrıca bu sof kumaşın dokunuşu, işlenişi ve ticareti hakkında önemli bilgiler vermişlerdir. Bu seyahatnamelerde sofçuluk, tiftik keçisi ve tiftik en çok bahsedilen iş kolu olarak görülmektedir (Tamur, 2003). Evliya Çelebi, 1648 yılında gittiği Ankara'nın sof şehri olduğunu, bu sofun başka yerde bulunamayacağını ve Ankara halkının işinin sof ve muhayyercilik olduğunu belirtmektedir (2008: s.527). Polonyalı seyyah Simeon, Ankara halkının çoğunun sof işiyle uğraştığını, dünyanın her tarafına kaliteli sof gönderildiğini belirtmiş ve her şehirden tüccarın Ankara'ya gelerek ve yerleşerek kumaş işiyle uğraştığını söylemiştir (Özkan 2012: s. 261). İngiliz gezgin William James Hamilton XIX. yüzyılın başlarında Ankara'da tiftik keçisi ticaretinin çoğunlukla Ermeniler tarafından gerçekleştirildiğini ve yöre olarak da özellikle Beypazarı halkının tiftik yetiştiriciliğinde önde olduğunu belirtmiştir (Erler, 2010). Michelle Membre, Ankara'dan “Zambelotti yapılan yer" olarak söz ederken zambelotti dediği şeyin sof olduğu anlaşılmaktadır. Ankara sofu o yüzyıllarda dünyanın hiçbir yerinde dokunamayan ve sağlamlığı ve güzelliği ile ün yapmış Cymatilis adıyla da anılmaktadır (Yanar ve Akpınarlı, 2016: s.172). Fransız Texier Beypazarı'nda karşılaştığı ticari canlılığ1 Avrupa kentlerine benzetmiş bu canlılığın nedeni olarak da sof üretimi ve ihracatı olduğunu ileri sürmüştür arka planında sof ihracatının bulunduğu ifade edilmektedir (Webb, 2011).

XVII. yüzyılda uluslararası giyim kuşam endüstrisinde bir rekabet söz konusu iken bu rekabet içerisinde yünlü kumaşların üretiminin öneminin arttığı ve keçi kılından elde edilen kumaşın Avrupa'da rağbet gördüğü bilinmektedir (Yücel ve Yenişehirlioğlu, 2018: s.12).

Ankara'da ticaretin hareketli ve yoğun olması kente İstanbul, Kayseri, Bursa vb. şehirlerden ve farklı ülkelerden birçok yerli ve yabancı tüccarın gelmesine neden olmuştur. Ankaralı tüccarların yurtdışına sofa dayalı ürünleri göndermek üzere yaptıkları ticari faaliyetlerin yanı sıra yabancı tüccarların da sof almak üzere şehre geldikleri bilinmektedir. XVI. yüzyılda Ankara'da üretilen sof ve şaliler yerli ve yabancı tüccarlar tarafından bir yandan İstanbul, Bursa, Halep, Şam gibi iç piyasada pazarlanırken İngiltere, Hollanda, Fransa, İspanya ve diğer Avrupa ülkelerine de ihraç ediliyordu (Ergenç, 2012: s.153). Ankara XVII. yüzyılda da önemli bir ticaret merkezi olması nedeniyle devletin her tarafindan tüccarlar gelmeye devam etmiştir. Özellikle, Kayseri, Tokat, Erzincan, İstanbul, Bursa, Van, Kefe, Karaman, Sivas, Erzurum, Sinop, Macar, Eflak, Boğdan gibi yerlerden gayrimüslim tüccarlar gelerek sof ticaretine yönelik faaliyetlerde bulunmuşlardır (Çetinkaya, 2020: s.101).

Sof üretimi ve sofa dayalı ticarete yönelik faaliyetler arşiv belgelerine de yansımıştır. Bir lüks tüketim malı olarak sof İstanbul için çok önem arz etmekte olup sarayın ve hanedanın özellikle tercih ettiği bir kumaştı. Bu nedenle sarayın ihtiyacı olan sof kumaşı Ankara'dan temin edilmekteydi. 1117/1705 y1lına ait bir belgede talep edilen sofların renk ve özellikleri arasında; tavşan kanı sof, al sof, açık şarabi sof, açık yeşil sof, açık nefti sof, fistıki yeşil sof, açık narenci sof, siyah sof, gülgüni sof, koyu menevş sofları bulunduğu belirtilmektedir (AŞS, 84: s.41/64) Devlet görevlilerinin kıyafetleri için sof ve şali talep ettiklerini bir belgede şu şekilde görmekteyiz. 1161/1749 yılında Anadolu valisi Mehmet Paşa, çeşitli sof türlerine ihtiyaç duyduklarını ve bu nedenle de Ankara'dan 1000 kuruşluk sof tedarik edilmesini (AŞS, 131: s.98/193). Ayrıca sof ipliğinin ve sofa dayalı ürünlerin satışının gerçekleştirilmesi için İstanbul en önemli pazar merkezlerinden biriydi (AŞS,84: 43/76). Bu nedenle Ankaralı sof tüccarlarını İstanbul'da görmek mümkündü. Sof üretim ve ticaret merkezi olan Ankara'nın ilişkisi yalnızca İstanbul ile sınırlı değildi. 1064/1654 tarihli bir belgede Ankara'nın sof ticaretinin yalnızca yakın çevresi ile değil İstanbul, Anadolu ev Rumeli'yi de içine alacak şekilde geniş bir alana yayıldığını göstermektedir (AŞS, 64: s.383). İstanbul gibi İzmir de Ankara tüccarı için bir pazar imkanı sağlıyordu. Ankaralı tüccarlar bir taraftan İzmir'e sof satışı yapıp diğer taraftan bu kentten boya, kalay ve çuha satın alıyorlardı (AŞS, 91: s.11). Bu dönemde başta İstanbul olmak üzere, İzmir ve Haleb'e gönderilen tiftik ipliklerinden Ankara damga mukâtaasının gelirleri arasında yer alan çıkar bâcı adı altında vergi alınmaktaydı (AŞS, 41: s.395). Kumaş ticaretinde gelişmiş olan Bursa coğrafi olarak Ankara'ya yakınlığından dolayı ticarî açıdan önem arz etmekteydi. Ankaralı tüccarlar ipekli dokuma kumaş satışı için Bursa'da bulunmaktaydı (AŞS, 89: s.36).

Uluslar arası pazarlarda da sof kumaşı önemli bir değere sahipti. 1112/1700 tarihli bir belgede sof kumaşın Mısır'a ihraç edildiği karşılığında da kahve alındığı belirtilmektedir. Ayrıca sof ve kahve ticareti üzerine bir ticari ortaklık da söz konusudur. Ankara tüccarlarından Zindancızade el-Hac Mehmed Efendi, Kahire'de elHac Musa Çelebi ortak bir şirket kurarak sof ve kahve ticareti gerçekleştirmişlerdir. Bu da şunu gösteriyor ki sof Ankara, kahve de Mısır için önemli bir ticari metadır (AŞS, 80: s.293/409). 
Ankaralı tüccarların sof ile ilgili ticarette kullandıkları bir ürün de sof ipliğinin boyanmasında kullanılan mazı diye bilinen bir tür boya malzemesidir. 1128/1716 y1lına ait bir belgede Ankaralı bir tüccarın mazı ticareti amacıyla Diyarbakır'da bulunduğu bilinmektedir (AŞS, 91: s.10).

Ankara'da sof üretimi ve ticareti Ankara, Anadolu ve Rumeli ile sınırlı kalmamıştı. Sof, aynı zamanda gerek Ankaralı tüccarların gerekse yabancı tüccarların ülkeler arası ticaretini yaptıkları bir meta idi. XVII. yüzyılda Avrupalı tüccar XV.-XVI. yüzyıllarda sadece sof ticareti ile ilgilenirken XVII. yüzylldan itibaren bu ticarete ek olarak tiftik ipliği ticaretine de yönelmişlerdir. Osmanlı sınırları içerisinde yapılan sof ticaretinde Müslimler kadar gayrimüslimlerin faaliyetleri de yaygındı. Hem Ankaralı gayrimüslim tüccarlar aracılığıyla hem de Ankara'ya ticaret için gelen yabancı tüccarlar aracılığıyla sof ve sofa dayalı ürünler yurtdışına götürülmüştür. Özellikle XVII. yüzyılda Ankara'nın uluslararası ticaretinde ve sofun Avrupa ülkeleri yanı sıra farklı şehirlere ulaştırılmasında gayrimüslimlerin Müslimlerden daha etkin rol oynadıklarını söylemek yanlış olmaz (Taş, 2006: s.68).

Ankara'da gayrimüslim tüccarların sofa dayalı ticarî faaliyet yürüttüklerini örnekleyen bir belgede, ticareti yapılan ürünler arasında elvan sof, şali gibi kumaş türleri yer almaktadır. 1162/1750 tarihli bir belgede Ankara'da Kanoş, Arton ve Kevrek adlı kardeşlerin ortak olarak Ebubekir Efendi'den 214 kuruşluk çeşitli elvan sof ve şali aldığı ancak paranın ödenmesi konusunda sıkıntılar yaşandığı yer almaktadır (AŞS, 133: s. 38/80). 1113/1701'de Ankara'nın Ayaş karyesinde Hacı beşe, Hace Masar adlı gayrimüslime 100 kuruşluk tiftik ipliği satışında bulunmuş ve 21 kuruşunu almış kalan 79 kuruşu ise sonrasında kefil olan kardeşi Hace Şahin'den talep etmiştir (AŞS, 80:s.161). Konyalı Mustafa Ankara'nın Yenice mahallesinden Mehmed ile 27 kuruşluk sof ticaretinde bulunmuştur (AŞS, 80: s.688).

Belgelerde Ankara'da oturup İstanbul, Halep, Kayseri, İzmir, Sivas, Erzurum ve Kudüs gibi bazı şehirlerine giden tüccar gayrimüslimler de bulunmaktaydı. Yine kayıtlarda bu şehirlerden başka Kahire’ye, Tebriz'e ve Venedik'e sof götüren tüccarlar olduğu da tespit edilmiştir (Akt: Çetinkaya, 2020: s.104). Ayrıca yabancı tüccarlar mal ihraç etmeyerek Osmanlı toprakları içinde de mallarını pazarlamak için ticari faaliyette bulunuyorlardı (AŞS, 131: s.98). Bu amaçla yabancı tüccarların yerli tüccarlarla alışveriş yaptıkları en önemli hanlardan biri Çengel Hanı idi. 1133-1721 tarihli bir belgede Çengel Hanı'nda sakin olan Mirat adlı kişinin Hollandalı tüccara 750 vukiyye sof ipliği sattığı belirtilmektedir (AŞS, 97: s. 13/16).

Ankara'da Damga mukâtaasına dahil olan gelirlerin başında ticarete konu olan mallardan alınan damga vergisi gelmekteydi. Özellikle de vergi gelirleri içerisinde en büyük payı sof satışından elde edilen gelirler oluşturmaktaydı. İzmir'de tahsil edilen rişte-i sof vergisi de Ankara Damga mukâtaasına dahildi. İzmir ve Ankara kadılarına gönderilen bir belgede damga mukâtaasına dahil iki köyün hasılatının, damga gelirlerinin, boyahane gelirlerinin ve İzmir'e gönderilen sof ipliğinden gerek Ankara'da gerekse İzmir'de alınan resimlerin toplanılarak her ay Darbhane-i Âmire hazinesine gönderilmesi istenmiştir (AŞS, 208/894: ss.529-530).

1093/1682 tarihli bir belgede Müslim ve gayrimüslim tüccarların tiftik ipliği ticaretinden dolayı Damga mukâtaasına olan borçları yer almaktadır (AŞS, 64:392).

Tablo 1.Tüccarların Damga Mukâtaasına olan Borç Miktarları (1093/1682)

\begin{tabular}{|l|l|l|l|}
\hline Tüccar & Esedi Kuruş & Tüccar & Esedi Kuruş \\
\hline Haramzâde Seyyid Muharrem Çelebi & 10 & Zimmî Abraham & 16 \\
\hline Şefka oğlu Masrûfî & 253 & Zimmî Gani Balı & 10 \\
\hline Peştemâlî oğlu Şahin & 120 & Andrik oğlu Serkis & 50 \\
\hline Kiras & 242 & Zimmî Yorgaki & 50 \\
\hline Kayserili Minnet & 60 & Haham Yahudi & 50 \\
\hline Muslu Ağa & 88 & Zimmî Lefter & 40 \\
\hline Bâzergânı Sinor & 206,5 & Yahudi Hoca İshak yediyle teslîm olunan & 141 \\
\hline Zimmî Hoca Bahşi & 20 & & \\
\hline \multicolumn{1}{|l}{ Kaynak: ASSS, 64:392 } & &
\end{tabular}

Tablo 1'den de görülebileceği üzere Ankara'da sof ve tiftik ipliği ticareti ile uğraşan Müslim tüccarların yanı sıra önemli sayıda gayrimüslim tüccar da bulunmaktadır. Özellikle borç miktarları incelendiğinde Bâzergânı Sinor adlı gayrimüslim tüccarın Ankara sof ticaretinde etkili olan isimlerden biri olduğu söylenebilir.

Sof ticaretine XVII. yüzyıl başında İngilizler ve yüzyılın sonlarında da Hollandalılar katılmıştır. Hollandalı tüccarlar Osmanlı ile kumaş ticareti yaparak Ankara'dan sof ve sof ipliği almışlardır (AŞS: 80, s.434). XVII. ve XVIII. yüzyıllar boyunca Ankara'ya sof ticareti için daha çok İngilizler, Hollandalılar, Venedikliler ve 
Lehliler gelmişlerdir. Lehliler, XVII. yüzyılda Ankara'da en yoğun ticaret yapan kesimdir. Başta İstanbul ve Halep, sof ticareti için önemli liman şehirleri iken XVII. yüzyıl ortalarından itibaren İzmir Foça'da önem kazanmaya başlamıştı. Avrupalı tüccarlar kervan ticareti yoluyla Ankara'dan getirdikleri malları İzmir limanındaki gemilerine yükler ve götürürlerdi ( Taş, 2006: s.74). 1599 yılında 18 tüccar toplam 5.700 .000 akçe değerinde 162 yük sofu Halep ve Venedik'te satmak amacıyla toplamıştır (Doğan, 2017: s. 258). XVIII. yüzyılda İngiliz tüccarlar Ankara'da menzil satın alarak sof ticaretlerini gerçekleştirmişlerdir. 1113/1701'de İngiliz tüccarı Sinor David Mukaddem mahallisinden 400 kuruşa kendine ev satın alarak Ankara'nın sakini haline gelmiştir (AŞS, 80: s.389). Hollandalı Flemenk tüccarlar Ankara ve Beypazarı kazalarından sof kumaş ticareti gerçekleştirmiştir (AŞS, 80: s.801). Flemenk tüccar Sinor Anton Hac1 Arab mahallesinde yaşayan El Hac Üveys Çelebi arasında 2000 kuruşluk sofa dayalı ticaret yapılmıştır (AŞS, 80:434). Fransızların Osmanlı ile sof ticareti XVIII. yüzyılın başların yoğun bir şekilde iken yüzyılın ikinci yarısında sona ermiştir (Ergenç, 1988: s.515).

XVIII. yüzyılda Ankara'da sof ticareti sof kumaş olarak değil daha çok tiftik ipliği ihracı ile devam etmiştir. Avrupalı devletler özellikle İngiltere, Fransa ve Hollanda kaliteli tiftik ipliğini alıp kendileri işlemek istiyordu. Ayrıca Osmanlı Devleti ile Napoli ve Sicilya arasında 1740-1859 ve 1804-1859 tarihleri arasında düzenlenmiş olan Gümrük Tarife Defterlerinde sof ve şal ticaretinden de bahsedilmektedir (Turan, 1969).

Sof ticaretiyle ilgili toplanan vergilerin miktarı konusunda incelenen sicil kayıtlarından damga akçasının meblağına dair bir bilgiye ulaşılamamakla beraber belgelerde damga vergisi dışında alınacak çıkar bâcı miktarları bulunmaktadır. Ankara' da iplik yükü başına 1 guruş çıkar bâcı alınmaktadır. Ayrıca tiftik ipliğinden gönderildiği mahalleye göre değişen vergi miktarları alınmaktadır. İstanbul'a giden iplikten vukiyye başına 10; İzmir ve Halep'e giden iplikten 9 akça, bâc miktarının daha yüksek olduğu Beypazarında ise tiftik ipliğinden yük başına 4 guruş çıkar bâcı talep edilmektedir. XVIII. yüzyılın son döneminde tiftik, yapağı, mazı (vukiyyeden bir para), kökboya (vukiyyeden iki akça) ve koyun ve keçiye yönelik yeni vergiler konulmuştur. 1208/1793-94 yılında ülkenin her yerinde satılan yapağının her vukiyyesinden bir akça vergi alınması kararlaştırılmıştır. Yine aynı dönemde boya vergisine 30 para zam yapılarak sof ve siyah şalinin 1 topundan alınan sıbgiye vergisi 90 paraya; elvan-1 şalinin 1 topundan alınan sıbgiye vergisi 80 paraya ve portakali şaliden alınan vergi 120 paraya çıkartılmıştır (Karaman, 2005: ss.192-198).

\section{ANKARA'NIN SOF ÜRETIMINE DAYALI TICCARETININ GERILEMESİ}

XVI.-XVII. yüzyıllar boyunca Ankara sof ticaretinin merkezi durumundaydı. Tiftik ve softan edinilen gelir XVII. yüzyılda da devam etmişse de XVIII. yüzyılla birlikte bu gelir kaynağı azalmaya başlamış özellikle XIX. yüzyıla gelindiğinde Ankara'nın sof ve şali üretiminden el ettiği geliri nerdeyse bitme noktasına gelmişti. Dolayısıyla Ankara'nın sof geliri azaldığı için ticarette eski canlılığını yitirmişti. Artık sof üretmek yerine ham tiftik ihracına başlanmıştır (Özdemir, 1986: s.118).

Sof üretiminin merkezi olan Ankara'da yüzyıllar boyunca ham tiftiğin Ankara dışına çıkarılması yasaktı. Sofcu esnafi dokudukları sofları aracısız olarak esnafa ve tüccara satarlardı. Ancak zaman zaman kendilerini simsar olarak adlandıran kişiler türeyerek sof ticaretinin kendilerine ait olduğu iddiasıyla sof satışını üstlenerek top başına bir iki guruş zam yaparak piyasada fiyatların yükselmesine yol açmışlardı. Bu durum hem sofcu esnafını hem de sof ticaretini olumsuz yönde etkilemiştir (Karaman, 2005: ss.193-194). Sof kumaşlarının dokunmasında Ankara tüccarının ihtiyaç duyduğu maddelerden biri olan şap, kumaşın yıpranma, güneşe karşı dayanıklılık ve boyanın sabitleşmesini sağlanmasında kullanılıyordu. Dolayısıyla dayanıklı bir sof kumaşı için olmazsa olmaz bir madde idi. Ancak başlarda Kütahya ve Karahisar-1 Şarki şapları kullanırken sonraki dönemlerde ucuz Avrupa şapları kullanılmaya başlandı. Avrupa şapları kumaşların yapısını bozarak kalitesini düşürdü. Yine sof kumaşının dokumasında kullanılan kökboyaların da Avrupa'dan getirilip Ankara'da ucuza satılması kumaş kalitesini düşüren ve bu yolla ticaretini etkileyen bir durumdu (Özdemir, 2012:371).

XVIII. yüzyılın son döneminde Fransızlar'ın Mısır'ı işgal etmeleri Osmanlı ile Mısır arasındaki ticaretin sekteye uğramasına yol açmıştır. Ankara'nın en önemli ticaret merkezlerinden biri olan Mısır'ın işgal altında olmas1 sof ticaretini olumsuz yönde etkilemiştir (Özdemir, 2012). Sof konusunda dünyada Osmanlı Devleti'nin tekelini kırmaya çalışan Avrupalı Devletler ve özellikle İngiliz tüccarlar söz konusuydu (Webb, 2011). Bu konuda ilk çalışma XVII. yüzyılda Fransa'da başlamış ve Anadolu'dan aldıkları Ankara tiftik keçilerini kendi ülkelerine götürmüşlerdi. Ancak iklim değişikliği nedeniyle keçiler burada türlerinin özelliklerini kaybetmişlerdi. Fransızlardan sonra XVIII. yüzyılda Hollandalılar ve İngilizler Ankara tiftik keçilerini alarak yetiştirmeye çalışmışlar ama onlar da başarısız olmuşlardı (Keskin, 2012: s.739).

İngiltere'de yüksek kapasiteli tiftik işleme tesislerinin varlığından dolayı Ankara'daki tiftik üretiminin \%40'1 bu ülkeye ihraç ediliyordu. Sanayi Devrimi sonrası İngiltere'nin dokuma sanayisindeki atılımları sonrası Ankara kumaş ticaretindeki önemini bir süre daha koruyabilmiş ancak XIX. yüzyılda mecburen tiftik 
ipliğinden ham tiftik ihracına geçiş yapmıştır (Tamur, 2003). XIX. yüzyılın başlarında Ankara ve çevresinde 10.000 kişinin çalıştığ 2000 adet dokuma tezgâhı varken yüzyılın sonlarına doğru tiftik ipliği ve kumaş üretimi bitme noktasına gelmiştir. Bunun en önemli nedenleri arasında İngilizlerin Afrika'da yetiştirdikleri keçilerin etkisiyle piyasaya gereğinden fazla mal sürmeleri sonucu tiftik fiyatının düşmesi ve insanların ucuz ama kalitesiz sof kumaşlara olan ilgisinin artmasıdır (Quataert, 1999: s. 164). İngilizlerin tiftik keçisini yetiştirmeyi başarmaları bu sanayi ev ticaret dalının Ankara'da gerilemesine yol açmıştır. Ankara tiftik keçisi üretiminde artık tekel durumunda değildi.

XVIII.-XIX. yüzyıllarda Avrupalı tüccarlar Ankara ve çevresinden bazı aracılar vasıtası ile sofun hammaddesi olan tiftik ve tiftik ipliğini toplattırıp İzmir yolu ve İstanbul ile Avrupa'ya kaçırmaya başlamıştı. $\mathrm{Bu}$ ise Ankara' da keçi yetiştiriciliğindeki azalma ile birlikte tiftik ipliği temininde sıkıntı yaşanmasına neden olmuştur. Tiftik keçisindeki azalmaya bağlı olarak tiftik keçisi postu, tiftik, tiftik ipliği, dokuma tezgâhı, boya ve boyama fiyatları ile usta ve işçi ücretleri de 5-6 kat artmıştır (Özdemir, 2012: ss.732-733).

Sanayi Devrimi sonrasında İngilizlerin makineleşmeye geçmeleri Anadolu'nun tiftikli dokumalarından sonra bükülmüş ipliğe olan talebi de azaltmış neredeyse bitirmiştir. Bunun sonucunda Avrupa'ya mamul mal yerine hammadde ihracı yapılmaya başlanmıştır. Tiftiğin ihracında meydana gelen bu değişim, sektörün genelinde bir gelir kaybına yol açarak başta dokumacılar ve iplik eğiricilerin tezgâhlarının boş kalmalarına neden olmuştur (Tan, 2014: s.142). Sonrasında tiftik sanayisine en büyük darbe 1838 Balta Limanı Ticaret Antlaşması ile indirilmiştir. Bunun sonucunda İngiliz dokumaları Osmanlı ve Ankara pazarına girmeyi başarmış ayrıca İngiltere'de Branford tiftik sanayisi de kurularak sektörde lider konuma yükselmişlerdir (Eşiyok, 2010).

\section{SONUÇ}

Eskiçağlardan itibaren pek çok seyyah ve tüccarın uğrak yeri olan Ankara ve çevresinin üretim ve ticari faaliyetleri XV. yüzyıldan itibaren belirgin bir şekilde sof üretimi ve ticareti üzerine şekillenmişti. Ankara'nın meşhur tiftik keçisinden üretilen sofun ekonomik getirisinin fazlalığı Ankara'yı bu alanda önemli bir kent haline getirmiş ve XV-XVIII. yüzyıllar boyunca Ankara ve çevresinde yaşayan halka iş imkânları ve canlı bir toplumsal yaşam imkanı sağlamıştır. Ankara'nın Anadolu'nun merkezi konumunda bulunmasının yanı sıra ticaret yollarının geçiş güzergâhında bulunması ve ticarî anlamda önem arz eden sof, şali, asdar üretiminde merkez durumunda olması bu kentte hem yerli hem de yabancı tüccarın yoğun olarak faaliyette bulunmasına olanak sağlamıştır.

Sof kumaşları çeşitli renkleri, desenlerdeki incelikleri ve dokuma esnasındaki ustalıklarıyla XVI. ve XVII. yüzyıllarda dünyaca tanınan bir kumaş haline gelmişti. Bu dönemde, şehrin üretim yapısı çok gelişmiş ve Ankara sofları şehrin çok önemli bir ihraç kalemi haline gelmiştir. Tiftik ipliğinden dokunan soflar, şehir ve çevresinin ihtiyacını karşılamanın yanı sıra çoğunlukla İstanbul ve yurtdışı pazarların talebini karşılamaktadır. Özellikle İngiltere, Hollanda ve Fransa'ya satılan kumaş Avrupa ülkelerinin yanı sıra Mısır gibi Arap ülkelerinde de satılmaktaydi.

Bu dönemlerde Ankara en büyük gelir kaynağını tiftik sektöründen elde ediyordu. Hatta XVIII. yüzyılda da dünya tiftik piyasasını sof ve sofa dayalı ticaretle elinde bulunduruyordu. Ancak özellikle XIX. yüzyılın ortalarından bu piyasada büyük bir çöküntü yaşanmaya başlanmış ve gelirler de önemli azalmalar olmuştur. Bunun en önemli nedenleri arasında, özellikle İngiltere ve Fransa gibi ülkelerin tiftik keçisi yetiştirmeye çalışmaları ve İngilizlerin bu alanda başarılı olmaları sonucu sof kumaşını daha ucuza üretmeleri, Sanayi Devrimi ile İngilizlerin makineleşme sürecine geçmeleri ve bu durumun Ankara'da geleneksel üretim teknikleri kullanan atölye ve tezgâhların dış pazarlar ile rekabet edememesine neden olması ve 1838 Baltalimanı Antlaşması ile İngilizlerin Osmanlı pazarlarına girmesi yer almaktadır. Tüm bu yaşananlardan sonra Ankara'da sof üretimi durma noktasına gelmiş ve Osmanlı'dan Avrupa'ya mamul mal yerine ham tiftik ihracına başlanmıştır. 


\section{KAYNAKÇA}

\section{Arşiv Belgeleri}

Ankara Şer'iye Sicili 21-24-41-64-67-80-84-89-91-97-131-133-191-208 nolu defterler

Akdağ M. (1995) Türkiye Halkının Dirlik ve Düzenlik Kavgası (Celali İsyanları), İstanbul: Barış Kitap.

Akyüz J., (2003) “Ankara’nın Bütüncül Tarihi Çerçevesinde XVIII. Yüzyılda Ankara (Şer’iye Sicillerinin Sayısal ve Muhtevâ Analizi Denemesi)", Basılmamış Doktora Tezi, Ankara Üniversitesi Sosyal Bilimler Enstitüsü, Ankara.

Ankara Kalkınma Ajansı (2018) Ankara Keçisi Tiftik ve Sof, Haz. Nurten Gülbay, Ankara

Çadırcı M., (1991) Tanzimat Döneminde Anadolu Kentlerinin Sosyal ve Ekonomik Yapıları, Ankara: Türk Tarih Kurumu Basımevi.

Çelebi, E., (2008) Günümüz Türkçesiyle Evliyâ Çelebi Seyahatnâmesi: Bursa-Bolu-Trabzon-Erzurum-AzerbaycanKafkasya-Kırım-Girit, 2. Cilt- 2. Kitap, Haz. Kahraman SA, Dağlı Y. İstanbul: Yapı Kredi Yayınları.

Çetinkaya, C., (2020) “Ankara'da Gayrimüslim Tüccarlar ve Sof Ticareti (XVII. Yüzyıl)”, Ankara Anadolu ve Rumeli Araştırmaları Dergisi, 1(1), s. 97-117.

Doğan, H. (2017) Osmanlı Devleti’nde Divani Sistemden Malikâne Sistemine Geçiş Süreci Ve Uygulamaları (1695 1730) - Ankara Ve Bursa Örneği-, Doktora Tezi, Kırıkkale Üniversitesi Sosyal Bilimler Enstitüsü, Kırıkkale

Erdoğan A, Günel G, Kılcı A (2007) “Tarih İçinde Ankara”, Ankara: Ankara Büyükşehir Belediyesi Yayını.

Ergenç Ö., (1980) Osmanlı Şehrinde Esnaf Örgütlerinin Fiziki Yapıya Etkileri, Türkiye'nin Sosyal ve Ekonomik Tarihi (1071-1920), Haz. Okyar O., İnalcık H. Ankara: Meteksan.

Ergenç Ö., (1988) “XVIII. Yüzyılda Osmanlı Sanayi ve Ticaret Hayatına İlişkin Bazı Bilgiler”, Belleten/LII, s.203, 501533.

Ergenç, Ö., (2012) XVI. Yüzyılda Ankara ve Konya, İstanbul: Tarih Vakfı Yurt Yayınları.

Erler M. M., (2010) Animals during disasters. In, Faroqhi S (Ed): Animals and people in the Ottoman Empire. İstanbul: Eren Yayınları.

Eşiyok, B. A., (2010) “Osmanlı İmparatorluğu’nun Dünya Ekonomisine Eklemlenmesinde Bir Dönüm Noktası: 1838 Serbest Ticaret Antlaşması”, Mülkiye Dergisi, C. XXXIV., s. 266.

Faroqhi S., (tarihsiz) “On yedinci Yüzyıl Ankara’sında Sof İmalatı ve Sof Atölyeleri”, İktisat Fakültesi Mecmuası, 41(14), s. 237-259.

Genç M., (1986), Osmanlı Esnafı ve Devletle İlişkileri, Ahilik ve Esnaf Konferanslar ve Seminer, Metinler-Tartışmalar, İstanbul: Esnaf ve Sanatkârlar Dernekleri Birliği Yayını

Karaman, D. (2005) “Şer'iye Sicillerine Göre XVIII. Yüzyılda Ankara Damga Mukâtaası”, Bilig Dergisi, Kış/ 2005, s.32, $179-222$.

Keskin, Ö. (2012) “Ankara Keçisinin Islahına Yönelik Tedbirler”, Tarihte Ankara Uluslararası Sempozyumu Bildiriler, Ankara.

Özdemir, R., (1986) XIX. Yüzyılın İlk Yarısında Ankara, Ankara: Kültür ve Turizm Bakanlığı Yayınları.

Özdemir R (2012) “Ankara'da Sof ve Şal Üretimi (1770-1850)”, Tarihte Ankara Uluslararası Sempozyumu Bildiriler, C.2, edit: Y. Kurt, (Ankara Üniversitesi DTCF Tarih Bölümü, Ankara:722-735).

Özkan T., (2012) “Seyahatnamelerde Ankara”, Tarihte Ankara Uluslararası Sempozyumu Bildiriler, C.1, Ed: Y.Kurt, Ankara.

Pakalın, M.Z., (1993) Sof, Osmanlı Tarih Deyimleri ve Terimleri Sözlüğü, 3.bs., İstanbul: MEB Yayınları.

Quataert, D., (1999) Osmanlı İmalat Sektörü/ Sanayi Devrimi Çağında, İstanbul: İletişim Yayınları

Sahillioğlu, H., (1968) XVIII. Yüzyıl Ortalarında Sanayi Bölgelerimiz ve Ticari İmkânları, Belgelerle Türk Tarihi, s. 11.

Tamur E., (2003) Tiftik keçisi ve Ankara Tiftik Dokumacılığı: Tükenen Bir Zenginliğin Ve Çöken Bir Sanayinin Tarihsel Öyküsünden Kesitler. Ankara Ticaret Odası, Ankara.

Tan, S., (2014) XIX. Yüzyılda Anadolu'dan Güney Afrika’ya Tiftik Keçisinin Yasal ve Kaçak Sevkiyatı, OTAM, XXXV, Ankara.

Taş, H., (2006) XVII. Yüzyılda Ankara, Ankara: TTK.

Tunçer, M., (2001) Ankara Şehir Merkezi Gelişimi (14.-20. YY), Ankara: T.C. Kültür Bakanlığı Yayınları.

Turan, Ş., (1969) Osmanlı İmparatorluğu ile İki Sicilya Krallığı Arasındaki Ticaretle İlgili Gümrük Tarife Defterleri, Belgeler, 2, s. 7-8, Ankara.

Webb Y. G., (2011) XVIII. Yüzyılda Osmanlı-İngiliz Tiftik Ticareti, Ankara: Türk Tarih Kurumu Basımevi.

Yanar, A. ve F. Akpınarlı, (2016) “Geleneksel Ankara Saf Dokumaları”, Ankara Araştırmaları Dergisi, 4(2), $170-179$.

Yücel G. Ç., ve Yenişehirlioğlu F., (2018) Tarihi Dokumak Bir Kentin Gizemi Sof, Ankara: Vekam Yayınları. 